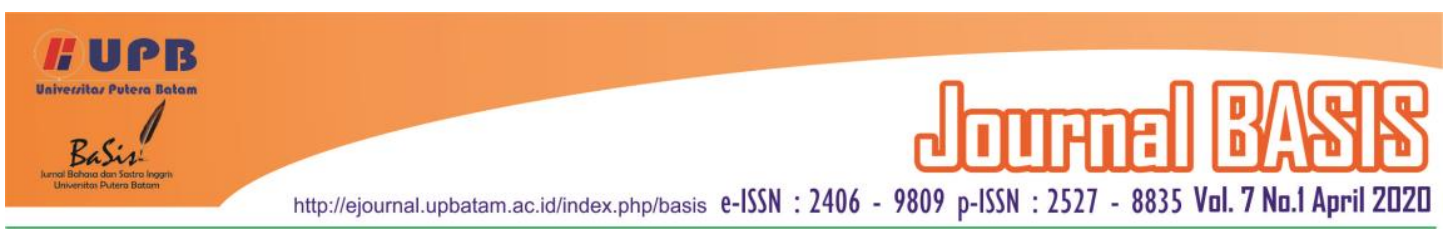

\title{
SITUATING WOMEN IN SOCIETY: A STUDY ON TRADITIONAL MANTRAS OF BANJAR
}

\author{
Ninuk Krismanti \\ STKIP PGRI Banjarmasin, Banjarmasin, Indonesia \\ ninukkrismanti@stkipbjm.ac.id
}

\begin{abstract}
The glory of traditional mantras of Banjar may have passed; however, mantras are still valuable products of traditional literatures of Banjarese society. This study was conducted to describe social treatments for women in the given society as reflected in traditional mantras. The data of the study were 35 love and conquering mantras extracted from four books. The data were collected through documentation technique. The data were analyzed using Antropholinguistics approach with two focuses of analyses: functions and contents. From functions and contents of mantras, the researcher interpreted the results of the study. After analyzing the data, the researcher concluded that women were still inferior compared to men. Women were the ones working harder to keep their position and relationship with men safe. Furthermore, their position in the society was sub-ordinate because the main roles given to them were domestic roles.
\end{abstract}

Keywords: traditional mantras; gender; women; society.

\section{INTRODUCTION}

In the past, literacy was a luxury only exclusives managed to afford. This explains why oral tradition blossomed more than the written ones in Banjarese society. Strong oral tradition in this society proves the fact that Banjar is an artsy tribe. Oral tradition is an integrated part of classic literatures. According to Taum (2011), classic literatures are divided into three kinds: poetry, folklore, and theater. Mantra is one of the classic literatures in poetry category. The characteristics of mantra meet all the characteristics of classic literatures: anonymous, collectively used, illogical, widely varied, and traditional, orally passed, and publicly owned (Danandjaja, 1997).

Mantras have passed their glory time. Nowadays, they are only used exclusively by limited people. This happened for several reasons. First, there is a rising awareness of avoiding the biggest sin in Islam, being an apostate or believing in other powers than Allah. Second, mantras are sacred in nature. Therefore, mantras are only passed to the chosen ones. Those who master the mantras tend to keep them for themselves because they believe mantras are previous things to be protected. Therefore, when they pass away without passing the legacy of mantras, the mantras die with them. Another reason why mantras are no longer used widely is because as life turns more modern and science and technology excel tremendously, people start leaving illogical practices.

However, by analyzing mantras empirically, we will be able to describe values and ways of lives of a community, including how women are situated and treated. Women inferiority in patriarchal society is not a new case. However, to claim Banjarese women 
less-fortunate position in the society is a case to be proven. Hence, this study was conducted to reveal the truth of women situation in context of Banjarese society through the analysis of its traditional mantras.

\section{REVIEW OF RELATED LITERATURES}

\subsection{Mantra}

Unilawati (2006,) defined mantra as a set of sacred words that posses magical power as long as strongly believed by its users. Mantra is part of oral literatures categorized as traditional poetry. Jauhari (2008) stated before the era of Buddhism and Hindu, around $10^{\text {th }}$ century, Banjarese people were animism and dinamism followers. Mantra was created because people believed that some bad things could be cured or avoided by doing reciting certain words and doing certain rituals. Only after the era of Buddhism and Hindu that mantra was named after those magic words. The word mantra is derived from Sankrit word meaning prayers or wishes.

After the era of Islam, the practices of previous beliefs and religions were not completely shifted into Islamic practices. Mantras were still used from generation to generation. However, after Islam became the religion of majority of people, the contents of the mantras were slightly changed. Bismillahirahmanirrahim (in the name of Allah, Most Gracious Most Merciful) marked the beginning of the mantras. Moreover, almost all mantras would be ended with Barakat Mangata La Illaha Illalah. The additional Islamic related words complete the contents of traditional mantras and show how these mantras are influenced by different beliefs and religions from time to time.

\subsection{Antropholinguistics}

Antropholinguistics is as a branch of linguistics that studies the relationship between language and culture, including how the language is used as daily means of communication among people. In other words, Antropholinguistics deals with how language is used contextually rather than structurally. Duranti (2000) outlined that Antropholinguistics is a useful approach to investigate meanings, functions, values, and norms of oral traditions.

Sibarani (2012) mentioned that as an interdisiplinary study, the focus of Antropholinguistics falls into three: (1) the study of language, (2) the study of culture, and (3) the study of other aspects of human life. The three are investigated through co-text, text, and context. Antropholinguistics enables reseachers to reveal local wisdoms of a community. The local wisdoms show identity of the community, or at bigger scale show identity of a nation.

\subsection{Previous Study}

There are two previous research related to mantras dan women social positions outlined in this study as comparison. The first study was conducted by Yulianto (2011). His research focused on the roles of mantras to depict the development of Banjarese culture. In his study, it was concluded that the texts of mantras portayed the changing of Banjarese culture from the era of animism and dynamism to the era of Islam. However, althouh mentioning that one of the purposes of mantras from different eras was for beauty, this study did not specify gender issues in the society.

The second study was conducted by Arianto \& Simanjuntak (2019). At the beginning, Arianto and Simanjuntak mentioned about the common belief in 
patriarchal system that puts women in oppresed and submissive positions. However, after studying the story of a sea ghost in Batam coast called Mak Ungkai, they drew the conclusion that Mak Ungkai, a woman, is far from the belief. Mak Ungkai was depicted as a powerful entity. She had the ability to protect the nature and the human. In other words, women are not always put in sub-ordinate position in the society. In relation to this study, Arianto and Simanjuntak (2019) studied similar topic to the researcher: women position. However, the approach and the subject of both studies are different.

\section{METHODS}

This study is a qualitative study. According to Bogdan and Bilken (2007), qualitative study is aimed to describe data from the subjects being observed. The data can be in forms of texts, utterances, or behaviors. Furthermore, Johnson and Waterfield (2004) mentioned that social phenomena must be interpreted, not measured. Thus, the design is suitable with the purpose of this study which is to interpret how women are treated in the society based on the language used in Banjarese traditional mantras.

The technique of data collection is documentation. The data of mantras are obtained and extracted from four books: (1) Mantra Banjar, (2) Sastra Lisan Banjar, (3) Sastra Banjar Genre Lama Bercorak Puisi, dan (4) Dandaman Kada Bapancung. Love and conquering mantras found from the books are listed and categorized based on their purposes. The approach applied to analyze the data is Antropholinguistics. The emphasis of Antropholinguistics is the relationship between language and culture. To answer the research question regarding how society situates women, the data are analyzed into two focuses: functions and contents of mantras.

\section{FINDINGS AND DISCUSSION}

4.1. Situating Women in the Society Based on Functions of Mantras

Someone recites mantras expecting certain results. In Banjarese society, mantras are recited mainly to obtain six wishes: (1) to heal sickness, (2) to conquer someone/something, (3) to show greatness, (4) to make someone fall in love, (5) to protect self, and (6) to be sent from afar. However, in this study, the mantras being the focus of investigation are limited to those related to women and men relationship. Therefore, out of the six wishes outlined previously, the writer analyzed only two categories: love mantras and conquering mantras. Other categories of mantras are neglected because they are not related to women and men relationship.

In there are 35 love and conquering mantras that the writer analyzed to reveal women's situation in Banjar. Of the 35, the mantras are further divided into 15 sub-categories based on their specific purposes. These 15 purposes of love and conquering mantras relating to men and women are:

1. To win woman (via cigarette as media)

2. To keep husband's feeling toward wife

3. To seduce woman

4. To seduce man

5. To win the woman rejecting before

6. To get someone's love

7. To look beautiful and gorgeous

8. To protect self (for bride to be)

9. To make husband loves being home

10. Mantra when taking a shower

11. Mantra when tying the hair

12. Mantra when going out from home

13. Mantra when seeing the mirror

14. Mantra when combing the hair

15. Mantra to make others respect us 
When seeing from the users of the mantras, there are nine mantras used by women, three mantras used by men, and three mantras used by both genders. The division is as follows:

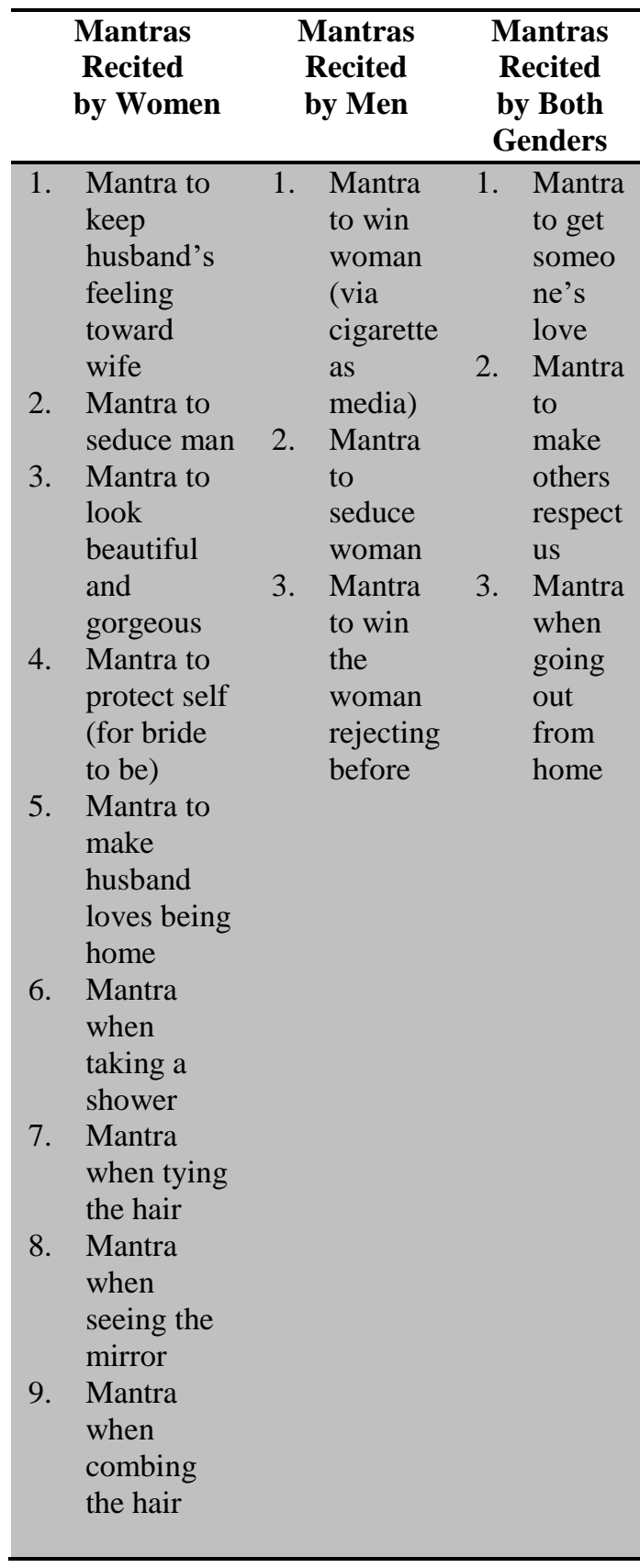

In relation to how women is situated in the society, the division above reflecting at least two things. First, in relationship with men, women are in inferior position. This is supported by the fact that they need more mantras for the relationship than men. Women need mantras for making men fall for them. The example of the mantra to make men fall for women is written below:

\section{Mantra 1}

Bismillahirrahmanirrahim
Tikna, tiknu
Hatinya, hatiku
Yaitu katanya kukang
Sali inya kawa pisah,
kukang laki bini maka
inya kada kawa bapisah
lawan diaku dengan
diriku
Yaitu katanya tuan ....
(sambat ngaran lalaki
yang dikahandaki/cintai)
Sali tuan kawa bapisah
lawan budaknya maka
inya kawa bapisah ma
lawan diaku
Makbul ucapanku
Barakat Lailahaillallah
Muhammadarrasullah

Furthermore, women recite two mantras to keep their loved ones near. One mantra is to keep their husbands' feeling toward them and another one is to make the husbands love being home. The mantra to keep the feeling the husbands have for the wives is as follow:

\section{Mantra 2}

\section{Ila putih siraum pandak \\ Siputih kada bakahandak \\ Kalau kada nang ampunnya}

Women also recite five mantras to take care of their look. They recite mantras to look gorgeous. They also recite mantras when taking a shower, tying their hair, seeing mirror, and combing their hair. This indicates their attempt to keep their appearance appealing for others, especially for their men. The example of mantras recited by 
women to keep their beautiful look can be seen in the following mantra:

\section{Mantra 3}

Ribu-ribu dikanan jalan

Sulasih digulai manis

Biar saribu urang bajalan

Aku jua diapandang urang manis

Tapungalas tapung ningasih

Tapungalas tapung ningila

Tauduk kasih

Tunduk gila

Inya mamandang aku

Barakat La ilaha illallah

Muhammadarrasullallah

Moreover, there are even mantras to protect the women from cheating or being cheated as they are about to get married. One of the mantras is as follow:

\section{Mantra 4}

\section{Sahangku si gunuk-gunuk Diluar di dalam sudah kusunduk Di luar di dalam sudah kukunci Naik rasa si laki-laki Sama di bawah sama awan di atas \\ Barakat mangata laillaha illallah Muhammadarrasulullah}

Women recite all of the mantras above to ensure that the men are pleased and the relationship is safe. When comparing to mantras recited by men, it is clear that the purpose of the mantras recited by men is only one: winning the desired women. On the other hands, men do not recite mantras to keep the women they love near nor do they recite them to make sure the relationship is in good terms. This shows that in relationship with men, women have tendency to work harder which show their sub-ordinate position in the relationship.
4.2. Situating Women in the Society Based on Contents of Mantras

Beside the functions, the contents of traditional mantras can also depict position of women. Based on the contents, when the mantras are for women, more parts of the mantras are about appearances and sexuality. Meanwhile, when the mantras are used by men, more parts of them are about masculinity or greatness of men. This again has proven women's inferiority compared to men as the words associated with them are shallower compared to what are associated with men.

Of 35 mantras becoming the data of the study, nine of them contain words regarding appearances. Women seduce men using mantras so that the men will see them as beautiful women. Beauty reflected in the mantras is related to luminous face, shining like the stars and the moon. There are seven mantras recited by women mentioning about the face. One of them is the following:

\section{Mantra 5}

Nuruwillah cahaya Allah

Nur Muhammad cahaya

Muhammad

Nur Fatimah ilila Fatimah

Kamandiakan ka tubuhku

Kunapaskan ka nyawaku

Barsari-sari ka muhaku

Barakat mangata laillaha illallah

Muhammadarrasulullah

The mantra above is recited by women when taking a shower. The mantra will only work when recited on Thursday night. The women shall take a shower while reciting this mantra for seven weeks. By doing this, it is expected that the women will be seen as beautiful ones by the men they desire. Not only when taking a shower, there are also mantras that shall be recited when the women are combing the hair, 
putting on face powder, serving the water for the men, and so on.

Other than appearance, mantras recited by women also contain words describing sexuality. One of them is the following mantra:

\section{Mantra 6}

\section{Patimah puhunnya rasa \\ Rasa patih rasa Patimah \\ Aku parampuan Patimah \\ Halal saparti banyu \\ Sintal saparti nasi \\ Kanyul saparti pulantan \\ Kasat saparti mambatak di \\ karangan putih \\ Karing saparti habu di dapur \\ Panas saparti bara api di dalam \\ tampurung \\ Harum saparti madu mangsah \\ Kipit saparti luang jarum \\ panyulam \\ Pintu lawang adamanku Patimah \\ Aku naik Nikmat \\ Aku mambari rasa kapada lakiku \\ Naik si bulu batis \\ Naik si bulu dada \\ Naik si bulu kapala \\ Tuhuk-tuhuk kajung-kajung ikam \\ Mamandang diaku \\ Barakat mangata laillaha illallah \\ Muhammadarrasulullah}

The mantra above is about how women expect their husbands to have desired for sex by only staring at the women and to be satisfied on bed. By reciting the mantra, it is hoped that the husbands will see their wives' body sexually appealing. This is to make sure that the husbands' sexual desires are fulfilled so that there is no need for them to find other women outside.

Another mantra showing sexual content is the mantra below:
Mantra 7

Suruiku surui banang

Kuandak di ganang-ganang

Badanku diganang-ganang

Tubuhku jua diangan-angan

In the mantra above, the women expect by reciting the mantra, their men will have sexual fantasy of them. The purpose of this mantra is again to ensure that the men will see only them.

Let us compare the mantras recited by women above with an example of mantras recited by men below:

\section{Mantra 8}

Bismillahirrahmanirrahim

Panahku panah Arjuna

Kupunahkan ka gunung, gunung runtuh Kupanahkan ka sungai, sungai karing Kupanahkan ka angin, angin tamandak Kupanahkan ka burung, burung gugur Kupanahakan lawan si .... ...., rabah, rubuh imannya kepadaku

Barakat La ilaha illallah

Muhammadurrasullah

Ruku, ruki

Patah tulang Baginda Ali

Rapat kuku lawan isi

Tiada lupa lawan diaku

Barang sehari-hari

Kataku si kata kukang

Makakung si nurmayu

Mayu kahandak Allah

Barakat La ilaha illallah

Muhammadurrasulallah

The mantra above is recited by men to make their desired women fall for them. The name of the mantra is Panah Arjuna (The Arrows of Arjuna). The words used in the mantra describe power and greatness. None of the words 
in the mantra above describe appearance or sexuality. The differences between contents of mantras recited by women and men have proven the inferiority of women in the society.

Women are long raised to believe that their main duty is to manage three things: kitchen, bed, and well. The world of women revolves around the house. They are raised to believe that they have to be able to keep the family well by doing good in cooking, sex, and cleaning. The domestication of women is a common thing in society. No matter how great women are at school or at work, they are the ones to blame when domestic chores at home are not wellmanaged. Meanwhile, men can go outside the house as they please without having the burden given to women. The contents of the investigated mantras further prove situation.

\section{CONCLUSIONS}

After analyzing traditional love and conquering mantras, the writer drew at least three conclusions. First, although reciting mantras is no longer a common practice of Banjarese people, mantras can be analyzed to reveal what happened in the society as language used in them is interrelated to how society members behave and what they believe. Second, the results of this study prove the inferior status of women in the society when compared to men. Third, whether or not the inferiority of women is still the case of modern Banjarese society needs to be further proven by the investigations of current written or oral literatures.

\section{REFERENCES}

Arianto, T., \& Simanjuntak, D. S. (2019). Paradoxical Representation of Female Narration in the Spirit of Mak Ungkai StoryNo Title.
Journal BASIS, 6(2), 173-184. https://doi.org/https://doi.org/10.33 884/basisupb.v6i2.1413

Bogdan, R. \& Bilken, S.K. (2007). Qualitative Research for Education: An Introduction to Theories and Methods $\left(5^{\text {th }}\right.$ Edition). Boston: Pearson.

Danandjaja, J. 1990. Folklor Indonesia: Ilmu Gosip, Dongeng, dan Lainlain. Jakarta: Grafiti.

Duranti, A. 2000. Linguistic Anthropology. Cambridge : Cambridge University Press.

Jauhari, A.M. (2008). Mantra Banjar: Bukti Orang Banjar Mahir Bersastra Sejak Dulu. In Jurnal Penelitian Meta Sastra. Bandung: Balai Bahasa Bandung.

Johnson, R. \& Waterfield, J. (2004). Making Words Count: The Value of Qualitative Research. Physiotherapy Research International. 9 (3), pp. 121-131. https://www.ncbi.nlm.nih.gov/pub med/15560669

Siberani, R. (2012). Kearifan Lokal: Hakikat, Peran, dan Metode Tradisi Lisan. Jakarta: Asosiasi Tradisi Lisan (ATL).

Sulistyowati, E. \& Tajuddin N. G. (2013). Sastra Banjar Genre Lama Bercorak Puisi. Kabupaten Banjar: Tuas Media.

Sunarti, P, Syamsiar, S, Syukrani, M, dan Saperi, K. (1978). Sastra Lisan Banjar. Jakarta: Pusat pembinaan dan Pengembangan Bahasa. 
Syahrani, A. (2015). Dandaman Kada

Bapancung. Banjarmasin: Pustaka Banua.

Taum, Y.Y. 2011. Studi Sastra Lisan: Sejarah, Teori, Metode, dan Pendekatan Disertai Contoh Penerapannya. Yogyakarta: Lamalera.

Tim Balai Bahasa Banjarmasin. (2016). Mantra Banjar. Banjarbaru: Balai Bahasa Banjarmasin.
Unilawati. (2006). Fungsi Mantra Melaut pada Masyarakat Suku Bajo di Sulawesi Tenggara. Kendari: Balai Bahasa Sulawesi Tenggara.

Yulianto, A. (2011). Mantra Banjar: Suatu Kompromi Budaya. Naditira Widya, 5(2), pp. 133140. Banjarmasin: Balai Arkeologi Banjarmasin. 